\title{
Reshaping the Society Face through The Culture of Horror Told in Shirley Jackson's The Lottery
}

\author{
Fani Alfionita Sari, Ajar PradikaAnanta Tur* \\ English Literature Department, Universitas Ahmad Dahlan \\ alfionitafani27@gmail.com \\ ajar.pradika@enlitera.uad.ac.id*
}

*Corresponding Author

\begin{tabular}{|c|c|}
\hline Article Info & ABSTRACT \\
\hline $\begin{array}{l}\text { Article History } \\
\text { - Article Received } \\
3 \text { February } 2019 \\
\text { - Article Reviewed } \\
20 \text { March } 2019 \\
\text { - Article Accepted } \\
1 \text { April } 2019 \\
\text { Keywords } \\
\text { perlocutionary act } \\
\text { the lottery } \\
\text { short story } \\
\text { culture of horror } \\
\text { society }\end{array}$ & $\begin{array}{l}\text { Building a new society can be implemented through cutting the chain of a certain } \\
\text { generation. Then, brainwash to younger one will be the powerful weapon to change } \\
\text { the face of the society by the authority. This study analyzes the use of perlocutionary } \\
\text { acts used by characters in Sirley Jackson's short story, The Lottery, that tells the } \\
\text { redaers about the culture of horror expressed by the characters to reshape the face } \\
\text { of the society. The descriptive qualitative method was used to investigate the essence } \\
\text { of the culture of horror through perlocutionary acts. Besides, the contextual method } \\
\text { was also applied to support the meaning of the culture of horror in the form of } \\
\text { narration in the short story. The result of this study is that the perlocutionary acts } \\
\text { used have } 4 \text { out of } 5 \text { parts according to the speaker's expression, namely: a) } \\
\text { convincing, b) inviting, c) blocking, d) surprising. Then the effects of this } \\
\text { perlocutionary act can create a horror effect based on the context, culture, and } \\
\text { background of the story. }\end{array}$ \\
\hline
\end{tabular}

\section{INTRODUCTION}

Because language is the one of the important part of human life, in this research, the researcher chooses speech acts to be the main theory. In human communication, there is not just sent a message, but more than that, there is implicit meaning by a sentence that spoken by someone. To know more about this case, the researcher decides to take speech acts to be the main topic in this research. The theory that will be used in this research is the consequences of perlocutionary act by Austin based on his book, entitled How to Do Things With Word. It was based on lectures given at Oxford between 1951 and 1954, and then at Harvard in 1955.

Speech act is one of the branch in pragmatics which examines the language of its actual usage aspect. Speech is a central entity within the pragmatics and is also the basis for the analysis of other topics in this area such as preappropriation, participation, conversational implicatures, principles of cooperation and the principle of politeness.

Performing perlocutionary acts is about what bring about or achieve by saying something, such as convincing, persuading, deterring, and even, say, surprising or misleading. Here there are three, if not more, different senses or dimensions of the 'use of a sentence' or of 'the use of language' (and, of course, there are others also). There are the consequences of perlocutionary act according to Austin [1] that are convincing, persuading, dettering, surprising, and misleading.

In this research, the researcher uses Shirley Jackson's The Lottery for the main data to analyze the perlocutionary act. "The Lottery" is a short story 


\section{Sari, Fani Alfionita \& Tur, Ajar Pradika Ananta. Reshaping the Society Face through The Culture of Horror Told in Shirley Jackson's The Lottery.}

written by Shirley Jackson, first published in the June 26, 1948 issue of The New Yorker. The story describes a fictional small town which observes an annual ritual known as "the lottery", which results in the killing of one individual in the town. This short story is chosen because there is many implicit meaning in every part of the story. Because of speech act is the theory that will be used, the researcher will focus on the quotation marks that is conversation of someone to someone else. The purpose of each spoken conversation will be analyzed to find out more about the purpose of the conversation, whether the conversation contains an implicit meaning or just convey the message according to the speaker said.

The researcher chooses Shirley Jackson's The Lottery because it was heavily criticized initially for the kind of horror of culture and customs it evokes. The author herself had led a troubled life of identity crisis and depression. It is why several critics argue that its influence has been on her works too. The era in which the story was written was one of social unrest and war. At the time the world was confronted with brutal realities of war and terror of the atomic bomb. Apart from that, the society was still not very well developed. It was also the time of rise of communism. This is shown throughout the story by the citizens not having a problem with the lottery until if affects them directly. Jackson's story also shows the sense of division and sexism between men and women associated with that decade. The idea of women being forced from one position of power to a lower position is shown in the last scene of "The Lottery" when the "winner" Tessie Hutchinson is the one who receives the black dot and is stoned to death. She tries to fight for her life but in the end is over powered by society's rules. The final major historical symbol in the story is the "black box" the black box is a symbol of an age old tradition in the village. "The Lottery" has many meaningful of every utterance that can be analyze using Three-Fold of Speech Act by Austin to know the real meaning of certain utterance in that short story. Based on the result of data that grouping each part of the consequences of perlocutionary act, the researcher will show up the horror effect.

Horror is the one of the favorite genre. Many people interest on it. Horror effects are considered more challenging for many people than adrenaline stories than the other genres. Carrol [2] said for over a decade and a half, perhaps especially in the United States, horror has flourished as a major source of mass aesthetic stimulation. Indeed, it may even be the most long-lived, widely disseminated, and persistent genre of the post-Vietnam era.

\section{LITERATURE REVIEW}

This research runs the theory of language phenomena, through the three-fold speech act which is perlocutionary act and how it can show the genre of a story based on the dialogue in that story. Moreover, the approach must be suitable with this research. In this research, the writer uses pragmatic approaches. The pragmatic approach involves using the method which appears best suited to the research problem. Pragmatic means study of the meaning in messages or information.

\section{a. Pragmatics}

Cruse [3] said that Pragmatics relates to aspects of information in the broad sense conveyed through generally accepted language in the form of communication used and naturally depends on the meaning encoded conventionally in the form of language used, as well as the context in the form used (emphasis added). There is relationship of language with logic. So, to analyze the message in information, there is pragmatics.

Mey [4] also explained that the 'pragmatic turn' in linguistics can thus be describe as a shift from the paradigm of the language user. Messages and language users always has correlation. When a person says a sentence to someone else, there is probability that in the messages contains implicit meaning. Pragmatic try to analyze the meaning of the message.

Furthermore, Leech [5] explained pragmatics is the study of the use and meaning of utterances to their situations. The conversation of the certain society based on the situation occurred in their place. Over the years, pragmatic has become more important branch of linguistics, as the inadequacies of a purely formalist, abstract approach to the study of language have become more evident. In pragmatic model there is studies linguistic communication in terms of communicative goals and principles of 'good communicative behavior'.

Based on the three experts above, the pragmatic means the meaning of information uses language. Pragmatic analyzes the messages in information of the speaker. This shows that in the message conveyed by someone there are many meanings, including the explicit meaning and hidden meaning or implicit in it. 


\section{b. Context}

Context is how pragmatics focuses on the meaning of the words in interaction and how interator communicate more information than the words they use[6]. Dynamic is the concept of context. This can be understood by means of community interaction and communication that can be understood with each other.

Context is more than just a reference and understanding of what is being discussed, practically. That also makes our words even deeper[7]. Analyzing the speech of some can make us be more careful of receiving the messages. We can analyze the real meaning which is explicit or implicit meaning. This is make our words and sensitivity of someone's mind deeper.

Context has become a key notion in language study. Questions concerning actual language use have been raised and it has become obvious that they can only be answered if the scope of linguistics is expanded and reference is made to the context in which language occurs[8]. The different situation of speech is also different context, even though the speech has same words structure.

Based on the three experts above, the conclusion about context is the focus of situations of language uses. And also about how the hearer can receive the real meaning of message by speaker.

Context is sparated in 5 categories based on[6]. They are context out-side text, situational context, background knowledge context, and exophora, deixis, and intertextuality.

Cutting[6] explained speech act and their linguistic relation are culturally bound. They way to expressing speech acts vary from country to country, from culture to culture. The society in a village or a town will share the information or knowledge based on their own cultural background. Cultural is the general knowledge that most people carry with them in their minds, about areas of life. In Shierly Jackson's The Lottery, there is a tradition in a village. In summer, the societies will go to the square of the town to get a lottery. Someone who get the lottery will die by many stone that throw by the villgers to him. Because of that, the expressive speech in there is about die, afraid, and many more that related to horror thing.

\section{c. Speech Act}

Speech act theory discribes what utterences are intended to do, such as promise, apologise and threaten. Mey[4] said that the first thing one should notice is that speech acts are action happening in the world, that is, they bring about a change in the existing state of affairs.

There are six parts of speech act in Pragmatic and Discourse by Joan Cutting. There are Austin's view (1961) about three-fold speech act, the classification of speech act by Searle (1976), direct speech act, felicity condition, indirect speech act, interactional/transactional function.

In this research, the writer just uses Austin's view (1961) about three-fold speech act. Because the main problem in this research is to classify the three-fold speech act by dialogue script in Shirley Jackson's The Lottery, and then show up the horror effect of the short story by the classification of three-fold speech act.

Austin's insistence that" the total speech act in the total speech situation is the only actual phenomenon which, in the last resort, we are engaged in elucidating (how to do things with words 1962: 147).

Austin in [6] differentiates sentences and utterance into:

a. Locutionary act is the utterance of a sentence with determine sense. Locution is what is said.

b. Illocutionary act means the making of statement, offer, promise, etc. in uttering a sentence, by virtue of the conventional force associated with it. Illocution is the act of saying something.

c. Perlocutionary Act is the bringing about the effects on the audience by means of uttering the sentence, such effects being special to the circumstances of utterance. Perlocutionary act is what is done by uttering the words.

\section{d. Consequences of Perlocutionary Act}

When a conversation is happening, sometimes the hearer will give response of the speaker saying. This response can be analyze based on the uses of utterences. Perlocutionary act is the method to analyze this effect. If there is effect after a speaker said an utterence, it means there is perlocution act. It [1] is the bringing about the effects on the audience by means of uttering the sentence, such effects being special to 


\section{Sari, Fani Alfionita \& Tur, Ajar Pradika Ananta. Reshaping the Society Face through \\ The Culture of Horror Told in Shirley Jackson's The Lottery.}

the circumstances of utterance. Perlocutionary act is what is done by uttering the words[6]. Perform of perlocutionary acts is about what bring about or achieve by saying something, such as convincing, persuading, deterring, and even, say, surprising or misleading. Here there are three, if not more, different senses or dimensions of the 'use of a sentence' or of 'the use of language' (and, of course, there are others also)[1].

\section{a. Convincing}

Convincing means make subject believe that something is true[9]. Based on the perlocutionary act in this research, the writer uses convincing to show the horror effect of this short story. Saying something will often, or even normally, produce certain consequential effects upon the feelings, thoughts, or actions of the audience, or of the speaker, or of other persons. The one of the consequence is convince someone to believe an information. The writer focuses on the respons of the hearer after they hear the utterance of the speaker. These utterances based on the context which is to convince the hearer about something.

\section{b. Persuading}

Persuading is uses to make subject do something by giving them good reason for doing it[9]. Based on the perlocutionary act in this research, the writer uses persuading to show the horror effect of this short story. We may also perform perlocutionary acts what we bring about or achieve by saying something. Persuading is the one of perform in saying an utterance. The writer focuses on the respons of the hearer after they hear the utterance of the speaker. These utterances based on the context which is to persuade the hearer about something.

\section{c. Dettering}

Dettering means discourage (someone) from doing something, typically by instilling doubt or fear of the consequences. In the other hand, dettering is also prevent the occurrences of. Based on the perlocutionary act in this research, the writer uses dettering to show the horror effect of this short story. From doing something by informing the hearer, perhaps guilelessly yet opportunely, what the consequences of doing it would in fact be: and this applies even to. The writer focuses on the response of the hearer after they hear the utterance of the speaker. These utterances based on the context which is to detter the hearer about something.

\section{d. Surprising}

Surprising is an event, news ect. that is unexpected or that happens suddenly[9]. Based on the perlocutionary act in this research, the writer uses surprising to show the horror effect of this short story. It is certain that the perlocutionary sense of 'doing an action' must somehow be ruled out as irrelevant to the sense in which an utterance, including of dettering utterance.

\section{e. Misleading}

Misleading means giving the wrong idea or impression and making subject believe something that is not true[9]. Based on the perlocutionary act in this research, the writer uses misleading to show the horror effect of this short story. A judge should be able to decide, by hearing what was said, what locutionary and illocutionary acts were performed, but not what perlocutionary acts were achieved.

\section{e. Horror effect}

For over a decade and a half[2], perhaps especially in the United States, horror has flourished as a major source of mass aesthetic stimulation. Indeed, it may even be the most long-lived, widely disseminated, and persistent genre of the post-Vietnam era. In this era also, many people be more interest of horror genre than the other genres. It is being favorite genre in novel, film, short story, etc.

He plans to analyze horror as a genre. However, it should not be assumed that all genres can be analyzed in the same way. Westerns, for example, are identified primarily by virtue of their setting. Novels, films, plays, paintings, and other works, that are grouped under the label "horror" are identified according to a different sort of criteria. Like suspense novels or mystery novels, novels are denominated horrific in respect of their intended capacity to raise a certain affect. Indeed, the genres of suspense, mystery, and horror derive their very names from the affects they are intended to promote a sense of suspense, a sense of mystery, and a sense of horror. The cross-art, crossmedia genre of horror takes its title from the emotion it characteristically or rather ideally promotes; this emotion constitutes the identifying mark of horror.

Carroll[2] presumes that the genre is designed to produce an emotional effect, it attempts to isolate that effect and attempt to show how the characteristic structures, imagery, and figures in the genre are arranged to cause the emotion that she will call art- 
horror. This kind of horror is different from the sort that one expresses in saying.

The utterence of "I am horrified by the prospect of ecological disaster," or "Brinksmanship in the age of nuclear arms is horrifying," or "What the Nazis did was horrible." Call the latter usage of "horror," natural horror.

The argument has been that if horror is, in large measure, identified with the manifestation of categorically impossible beings, works of horror, all things being equal, will command our attention, curiosity, and fascination, and that that curiosity, as well, can be further stimulated and orchestrated by the kind of narrative structures that appear so frequently in the genre[2].

There are many subgenre of horror art. Some subgenres of horror art include low-budget horror, action horror, comedy horror, body horror, disaster horror, found footage, holiday horror, horror drama, psychological horror, science fiction horror, slasher, supernatural horror, gothic horror, natural horror, zombie horror, first-person horror, and teen horror.

\section{f. Shirley Jackson's The Lottery}

Short stories are short fictional narratives. Short stories tend to be less complex than novels. Poe[10], in his essay "The Philosophy of Composition", short stories usually focus on one event, have one plot, a single setting, a limited number of characters, covering a short period of time. The term short story generally refers to fictional works with no more than 20,000 words in length and no less than 1,000 words. Short stories in general are a form of fiction, and have a genre of fiction such as science fiction, horror fiction, detective fiction, etc.

"The Lottery" is a short story written by Shirley Jackson first published in the June 26, 1948 issue of The New Yorker. The story describes a fictional small town which observes an annual ritual known as "the lottery", which results in the killing of one individual in the town.

Shirley Jackson's The Lottery was heavily criticized initially for the kind of horror of culture and customs it evokes. The author herself had led a troubled life of identity crisis and depression. It is why several critics argue that its influence has been on her works too. The era in which the story was written was one of social unrest and war. At the time the world was confronted with brutal realities of war and terror of the atomic bomb. Apart from that, the society was still not very well developed. It was also the time of rise of communism. This is shown throughout the story by the citizens not having a problem with the lottery until if affects them directly. Jackson's story also shows the sense of division and sexism between men and women associated with that decade. The idea of women being forced from one position of power to a lower position is shown in the last scene of "The Lottery" when the "winner" Tessie Hutchinson is the one who receives the black dot and is stoned to death. She tries to fight for her life but in the end is over powered by society's rules. The final major historical symbol in the story is the "black box" the black box is a symbol of an age old tradition in the village.

This short story has negative response from the reader. The lottery is the one of the most famous short story. But, because of the ironic story, many people sent the hate mail to Jackson.

\section{METHODOLOGY}

Method is the one of the important things to get the result of a research. According to Rosdy Ruslan (2003: 24), methods are scientific activities related to a method of work (systematic) to understand a subject or object of research, as an effort to find answers that can be accounted for scientifically and including their validity. The use of method or technique depends on the characteristic of data. There are two kinds of research method which are qualitative method and quantitative method.

In this research, the researcher will use qualitative method. Creswell[11] said qualitative inquirers is used in a board explanation for behavior and attitudes and it may be complete with variables, construct, and hypothesis. The other suggestion about qualitative method is Moleong's explanation[12] that qualitative research is the research to understand the phenomena about many things that happens to the subject in the research.

Narrative research[14][15][16] will be the approach that will be used by the writer to find the consequences of perlocutionary act and show up the horror effect of Shirley Jackson's The Lottery using this perlocutionary act by Austin. This technique uses by finding data in the dialog of the short story, then be narrated in sentences form after classify the data which are included of perlocutionary act to show the horror effect of the short story. 


\section{RESULT AND DISCUSSION}

\section{A. Consequences of Perlocutionary Act}

1. Convincing

The writer focuses on the response in this utterances based on the context which is to convince the hearer about something.

"Clean forgot what day it was,"

In this data, there is a statement from Mrs. Hutchinson stated that he had forgotten if that day was the day when a tradition that had been passed down in the village. The effect of Mrs. Hutchinson's statement is Mrs. Delacroix responded with a very slow laugh, as written in the next sentence "Who stood next to her, and They both laughed softly." Laugh softly here because they were afraid about what will happen that day that is lottery which decide their lives.

\section{Persuading}

The writer focuses on the response in this utterances based on the context which is to persuade the hearer about something.

Mr. Summers said, "Some of you fellows want to give me a hand?"

Mr. Summer tried to persuade the person in the village who would later be used to hold the lottery tradition to bring the black box he was carrying. The response given by the listener is a feeling of hesitation to help. There was hesitation to help Mr.Summer, it means they were afraid. Although then there were two people, Mr. Martin and his son, who helped bring the black box.

\section{Dettering}

The writer focuses on the response in this utterances based on the context which is to detter the hearer about something.

"You didn't give him time enough to take any paper he wanted. I saw you. It wasn't fair!"

In this data, there is a message that is trying to block things that have happened and so that they do not continue and that it gives review of what has happened. In this case, Mrs. Hutchinson tried to block Mr. Summer to continue the lottery, because she felt there was something unfair in the lottery. Mrs. Graves and Mrs. Delacroix try to refute what was said by Mrs. Delacroix to Mr. Summer, ""Be a good sport, Tessie." Mrs. Delacroix called, and Mrs. Graves said, "All of us took the same chance."' Rebuttal effect given by Mrs.
Graves and Mrs. Delacroix is a response stating that Mrs. Hutchinson must be fair too.

\section{Surprising}

Based on the perlocutionary act in this research, the writer uses surprising to show the horror effect of this short story.

Then the voices began to say, "It's Hutchinson. It's Bill," "Bill Hutchinson's got it."

In this data, the villagers are guessing who will get the lottery because it has already been drawn. It turned out that the result was that the Hutchinson family got it. Therefore, a shocked expression emerged from the villagers by saying that the Hutchinson family got the lottery. These surprising expressions cause effects to listeners. People who talk enthusiastically because the lottery results can be determined. The response from listeners was also no less enthusiastic because they felt they were not victims.

\section{Misleading}

Based on the perlocutionary act in this research, the writer uses misleading to show the horror effect of this short story. According to Austin (1962:121), a judge should be able to decide, by hearing what was said, what locutionary and illocutionary acts were performed, but not what perlocutionary acts were achieved.

\section{B. Horror Effect of Perlocutionary Act}

Based on the data in the first problem formulation, the writer brings up the horror effect in Shirley Jackson's The Lottery. Thus, the analysis of horror effect as seen below:

Mr. Summers said, "Some of you fellows want to give me a hand?"

Mr. Summer tried to persuade the people there to bring the Black box he was carrying. But there were doubts about the person he was talking to help him. The black box was a box that can determine their fate whether to go home in good condition or die of being stoned after getting a paper with a black dot in black box. Based on the context, Mr. Martin and his oldest son, Baxter, came forward to hold the box steady on the stool after hear that utterence. But there was hesitation to help Mr.Summer, it means they were afraid. This is because there was something felt with the black box. The picturesque setting contrasts sharply with the horrific violence of the conclusion. 
"You didn't give him time enough to take any paper he wanted. I saw you. It wasn't fair!"

In this case, Mrs. Hutchinson tried to block Mr. Summer to continue the lottery, because she felt there was something unfair in the lottery. Mrs. Hutchinson protested what had happened and tried to block what would happen after the injustice happened. Sentences uttered by listeners have a horror effect because Mrs. Graves and Mrs. Delacroix was not afraid of what Mrs. Hutchinson said, but instead they have no sense of humanity that causes the impact of horror. Furthermore, this lack of humanity had an impact on the death of Mrs. Hutchinson. They told Mrs. Hutchinson to be fair.

\section{CONCLUSION}

There are 4 from 5 consequences of perlocutionary acts are found in Shirley Jackson's The Lottery. The consequences consist of convincing, persuading, dettering, and surprising according to the result of the research.

The consequences of perlocutionary act have impact based on the context to show up the genre of Shirley Jackson's The lottery. Context in the form of a response from the listener after hearing the speaker's statement influences the determination of the genre in the short story. Besides the story background also supports the existence of a horror effect in the story.

\section{REFERENCES}

[1] Austin, J.L., 1962. How to Do Things with Words, 2nd Edition, ed. J.O. Urmson and M. Sbisá. Cambridge, MA: Harvard University Press.

[2] Carroll, Noel. 1990. The Philosophy of Horror or Paradoxes of Heart. New York: Routledge.

[3] Cruse, A. 2006. A Glossary of Semantics and Pragmatics. Edinburgh University Press.

[4] May, Jacob. 2001. Pragmatics an Introduction. Blackwell Publishing.

[5] Leech, G. N. 2016. Principles of pragmatics. Routledge

[6] Cutting, Joan. 2002. Pragmatic and Discourse. London: Routledge.
[7] Akmajian, Adrian, dkk. 2001. Linguistics: An Introduction to Language and Communication. MIT Press.

[8] Illes, Eva. 2001. The Definition of Context and its Implications for Language Teaching. University of London Institute of Education. p.11.

[9] Oxford Dictionary. 8th edition. Oxford University Press.

[10] Poe, Edgar Allan. 1846. The Philosophy of Composition. Philadelphia: Graham's Magazine.

[11] Creswell, John W. 2009. Research Design. 3th edition. United States of America: SAGE Publication Inc. p.61.

[12] Moleong. 2007. Metode Penelitian Kualitatif. Bandung: PT. Remaja Rosdakarya Offset.

[13] Creswell, John W. 2007. Qualitative Inquiry and Research Design. 2th edition. United States of America: SAGE Publication Inc. p.6.

[14] Kesuma, Tri Mastoyo Jati. 2007. Pengantar (metode) Penelitian Bahasa. TMJ Kesuma. Yogyakarta: Carasvatibooks.

[15] O'Donoghue, T., Punch K. 2003. Qualitative Educational Research in Action: Doing and Reflecting. Routledge. p.78.R

[16] Ruslan, Rosady. 2003. Metode Penelitian PR dan Komunikasi. Jakarata: PT. Raja Grafindo Persada. 